\title{
Bronchial reactivity in green coffee exposure
}

\author{
EUGENIJA ŽUŠKIN, ' BOŽICA KANCELJAK, ${ }^{2}$ ZDENKA SKURIĆ,' AND D BUTKOVIĆ' \\ From the Andrija Stampar School of Public Health ${ }^{1}$ and Josip Kajfes Hospital, ${ }^{2}$ Zagreb, Yugoslavia
}

\begin{abstract}
Respiratory symptoms and lung function were studied in nine coffee workers who complained of job related respiratory symptoms. Six described symptoms characteristic of occupational asthma. Lung function data showed obstructive changes mostly in the smaller airways with no impairment in diffusing capacity. Bronchoprovocation testing with green coffee allergen provoked immediate asthmatic reactions with acute reductions of ventilatory capacity in four workers. The relative fall in $\mathrm{FEF}_{25-75 \%}$ (ranging from $28 \%$ to $66 \%$ ) was greater than in $\mathrm{FEV}_{1}$ (ranging from $18 \%$ to $62 \%$ of the control values). Eight of the nine workers had an increased total IgE serum level; five had positive intradermal skin tests to green coffee allergen. Most of the six healthy subjects experimentally exposed to green coffee dust in the working environment showed an acute fall in flow rates on maximum expiratory flow-volume curves. These results indicate that bronchoprovocation with green coffee allergen or green coffee dust may be used to identify subjects sensitive to green coffee.
\end{abstract}

Asthma or other allergic symptoms in coffee workers have been described by several authors suggesting a reagin mediated reaction to inhaled green coffee..$^{1-5}$ In our epidemiological studies of the effect of coffee dust on respiratory function in coffee workers we found that several coffee processors complained of respiratory symptoms accompanied by acute or chronic changes in lung function. ${ }^{67}$ Somazi and Wütrich showed an acute decrease in lung function after the inhalation of green coffee allergen, ${ }^{8}$ and Karr et al reported a fall in FEV in two subjects after a bronchial provocation challenge with green coffee beans. ${ }^{5}$ Experimental studies with green and roasted coffee allergen on isolated guinea pig tracheal smooth muscle have indicated a bronchoconstrictive effect of green coffee dust."

In the present investigation lung function measurement and bronchial provocation testing with green coffee dust allergen were performed in coffee workers who complained of respiratory difficulties during the working shift. In addition, we studied acute lung function changes in healthy volunteers experimentally exposed to green coffee dust in the working environment.

Received 23 July 1984

Accepted 17 September 1984

\section{Subjects and methods}

\section{STUDY IN COFFEE WORKERS \\ Subjects}

Nine coffee workers (seven men and two women) employed in the coffee processing industry were included in the study. They all complained of chest tightness and difficulty in breathing while working with coffee. It was particularly pronounced after a break of two or more days. Their ages ranged from 22 to 40 with a duration of employment in the coffee industry ranging from 2 to 17 years (table 1).-

\section{Respiratory symptoms}

Respiratory symptoms were recorded by using the British Medical Research Council questionnaire ${ }^{10}$ with additional questions on occupational asthma. The following definitions were used:

Chronic cough/phlegm-Cough or phlegm production or both on most days for at least three months in the year.

Chronic bronchitis-Cough and phlegm for a minimum of three months in the year and for not less than two successive years.

Dyspnoea grades-Grade 2: shortness of breath with hurrying on level ground or walking up a slight hill; grade 3: shortness of breath when walking with other people on level ground; grade 4: shortness of breath when walking at own pace on level ground.

Occupational asthma: Chest tightness, cough, 
Table 1 Prevalence of respiratory symptoms in coffee workers

\begin{tabular}{|c|c|c|c|c|c|c|c|c|c|c|c|c|c|c|}
\hline \multirow[t]{2}{*}{ Subject } & \multirow[t]{2}{*}{ Sex } & \multirow[t]{2}{*}{$\begin{array}{l}\text { Age } \\
(y)\end{array}$} & \multirow[t]{2}{*}{$\begin{array}{l}\text { Exposure } \\
(y)\end{array}$} & \multirow[t]{2}{*}{$\begin{array}{l}\text { Chronic } \\
\text { cough }\end{array}$} & \multirow[t]{2}{*}{$\begin{array}{l}\text { Chronic } \\
\text { phlegm }\end{array}$} & \multirow[t]{2}{*}{$\begin{array}{l}\text { Chronic } \\
\text { bronchitis }\end{array}$} & \multirow[t]{2}{*}{ Asthma } & \multirow[t]{2}{*}{$\begin{array}{l}\text { Dyspnoea } \\
\text { grade }\end{array}$} & \multirow[t]{2}{*}{ Rhinitis } & \multirow[t]{2}{*}{ Sinusitis } & \multirow[t]{2}{*}{ Smoking } & \multicolumn{2}{|c|}{$\begin{array}{l}\text { Intradermal } \\
\text { skin test }\end{array}$} & \multirow[t]{2}{*}{ Igi } \\
\hline & & & & & & & & & & & & $R C$ & $G C$ & \\
\hline $\begin{array}{l}1^{*} \\
2^{*} \\
3 \\
4 \\
5 \\
6^{*} \\
7 \\
8 \\
9^{*}\end{array}$ & $\begin{array}{l}\mathbf{M} \\
\mathbf{M} \\
\mathbf{M} \\
\mathbf{M} \\
\mathbf{F} \\
\mathbf{F} \\
\mathbf{M} \\
\mathbf{M} \\
\mathbf{F}\end{array}$ & $\begin{array}{l}29 \\
29 \\
27 \\
40 \\
37 \\
31 \\
22 \\
25 \\
27\end{array}$ & $\begin{array}{r}3 \\
4 \\
2 \\
15 \\
17 \\
4 \\
2 \\
3 \\
5\end{array}$ & $\begin{array}{l}+ \\
+ \\
+ \\
+ \\
+ \\
+ \\
+ \\
+ \\
+\end{array}$ & $\begin{array}{l}- \\
+ \\
+ \\
+ \\
+ \\
- \\
- \\
+ \\
-\end{array}$ & $\begin{array}{l}- \\
+ \\
+ \\
+ \\
+ \\
- \\
- \\
+ \\
-\end{array}$ & $\begin{array}{l}+ \\
+ \\
+ \\
+ \\
- \\
+ \\
- \\
- \\
+\end{array}$ & $\begin{array}{l}2 \\
2 \\
3 \\
2 \\
3 \\
2 \\
2 \\
2 \\
2\end{array}$ & $\begin{array}{l}+ \\
+ \\
+ \\
+ \\
+ \\
+ \\
+ \\
+ \\
+\end{array}$ & $\begin{array}{l}- \\
- \\
- \\
- \\
- \\
- \\
- \\
- \\
+\end{array}$ & $\begin{array}{l}\text { NS } \\
\text { S } \\
\text { S } \\
\text { S } \\
\text { NS } \\
\text { NS } \\
\text { S } \\
\text { S } \\
\text { NS }\end{array}$ & $\begin{array}{l}- \\
\overline{-} \\
\overline{+} \\
++ \\
\bar{z} \\
\overline{-}\end{array}$ & $\begin{array}{l}++ \\
++ \\
+ \\
- \\
+ \\
++ \\
+++ \\
++ \\
++\end{array}$ & $\begin{array}{c}7 \\
4 \\
10 \\
1 \\
\vdots \\
1 \\
8 \\
2 \vdots\end{array}$ \\
\hline
\end{tabular}

*Positive bronchial provocation testing with green coffee allergen.

RC = Roasted coffee; GC = Green coffee.

Intradermal skin test: $+5-8 \mathrm{~mm} ;++9-11 \mathrm{~mm} ;+++12-20 \mathrm{~mm}$.

NS $=$ Non-smokers; $S=$ Smokers.

wheezing, and shortness of breath during exposure to dust at work.

The workers were also asked about allergic symptoms with specific emphasis on the intensity of such problems related to coffee dust exposure.

\section{Lung function measurement}

Ventilatory capacity was measured by recording the forced expirogram from which the forced vital capacity (FVC), forced expiratory volume in one second $\left(\mathrm{FEV}_{1}\right)$, and maximum mid-expiratory flow (MMEF) rates between $25 \%$ and $75 \%$ of the FVC $\left(\mathrm{FEF}_{25-75 \%)}\right.$ were read. In addition, maximum expiratory flow volume (MEFV) curves were recorded with a Pneumoscreen (Jaeger, West Germany). Flow rates at $50 \%$ and the last $25 \%$ of the vital capacity (MEF50\% and MEF25\%) were determined from the MEFV curves. Functional residual capacity (FRC), residual volume (RV), and total lung capacity (TLC) were measured with a spirometer Pulmotest (Gould, Godart, Netherlands). Diffusing capacity ( $\mathrm{DL}_{\mathrm{co}}$ ) was measured by the single breath method with a Resparameter (Morgan Ltd, England). To study the effect of a bronchodilator, the MEFV curves were repeated after inhalation of two puffs of bromhexine/ orciprenaline (Alupent).

The measured values were compared with the expected normal values of CECA ${ }^{11}$ for FVC, FEV ${ }_{1}$, and RV, of Morris et al for $\mathrm{FEF}_{25-75 \%},{ }^{12}$ of Cherniack and Raber for MEF50\% and MEF $25 \%,{ }^{13}$ and of Cotes for $\mathrm{DL}_{\mathrm{CO}} \cdot{ }^{14}$

\section{Immunological studies}

The workers were skin tested with aqueous extracts of green coffee and roasted coffee using the standard intradermal test. Coffee allergens were prepared from green and roasted coffee dust collected in the coffee industry in which the subjects were employed. In addition, intracutaneous testing was made with histamine base $(0 \cdot 1 \mathrm{mg} / \mathrm{ml})$ and buffer as control solutions. Intradermal skin tests with these allergens were performed using a dilution of 1:500 $(0.02 \mathrm{ml}$ of solution). The skin reactions were read after 20 minutes and were considered positive if the diameter of the weal was larger than $9 \mathrm{~mm} .^{15}$

Serum levels of total IgE antibody were measured by PRIST (Pharmacia Diagnostics AG, Uppsala, Sweden), a direct radioimmunological sandwich technique based on paper discs as the solid phase: ${ }^{16}$ An IgE level below $125 \mathrm{IU} / \mathrm{ml}$ was considered as normal (Behringwerke AG, Marburg-Lahn).

\section{Bronchial provocation testing}

The bronchial inhalation challenge was performed with an aqueous extract of green coffee allergen. Before the challenge all subjects were clinically normal and had normal ventilatory capacity. Bronchial challenge was also performed with physiological saline as a control; $1 \mathrm{ml}$ of physiological saline was placed in a Heyer Piccolo nebuliser (Carl Heyer GmbH, Bad Ems, West Germany) which, with an air flow of $15 \mathrm{l} / \mathrm{min}$ nebulised the fluid during inspiration only. If no response occurred to the inhalation of the placebo the procedure was repeated with $1 \mathrm{ml}$ of aqueous extract of green coffee allergen. The subjects were asked to inhale the whole amount of the solution (green coffee allergen or a placebo). The dose of green coffee allergen was determined on the basis of the reaction to the skin prick tests with the aqueous extract of green coffee allergen in a dilution 1:500. A weal of greater than $3 \mathrm{~mm}$ was considered to be a positive reaction. ${ }^{17}$ All workers were challenged with green coffee allergen in a concentration of 1:500.

Ventilatory function testing was performed before exposure and at 5, 10, and 20 minutes after the cessation of exposure. A positive response was defined as a $20 \%$ fall in $\mathrm{FEV}_{1}$ and a $25 \%$ fall in $\mathrm{FEF}_{25-75 \%}$ from the baseline after antigen challenge. 
Table 2 Lung function in coffee workers. (Percentages of normal values in parentheses)

\begin{tabular}{|c|c|c|c|c|c|c|c|c|c|}
\hline $\begin{array}{l}\text { Subject } \\
\text { No }\end{array}$ & Sex & $\begin{array}{l}\text { Age/weight } \\
\text { (yrs/cm) }\end{array}$ & $\begin{array}{l}F V C \\
(1)\end{array}$ & $\begin{array}{l}F E V_{1} \\
(1)\end{array}$ & $F E V_{1} / F V C \%$ & $\underset{(l / s)}{M E F_{25-75 \%}}$ & $\begin{array}{l}R V \\
(1)\end{array}$ & $\begin{array}{l}T L C \\
(1)\end{array}$ & $\begin{array}{l}D L C O \\
(\mathrm{mmol} / \mathrm{min} / \mathrm{kPa})\end{array}$ \\
\hline $1^{*}$ & $\mathbf{M}$ & $29 / 173$ & \multirow{9}{*}{$\begin{array}{l}5 \cdot 60 \\
(106 \cdot 1 \%) \\
6 \cdot 81 \\
(112 \cdot 1 \%) \\
4 \cdot 65 \\
(90 \cdot 6 \%) \\
5 \cdot 81 \\
(98 \cdot 0 \%) \\
4 \cdot 12 \\
(96 \cdot 6 \%) \\
5.05 \\
(117 \cdot 0 \%) \\
5 \cdot 73 \\
(91 \cdot 2 \%) \\
5 \cdot 17 \\
(92 \cdot 3 \%) \\
3 \cdot 78 \\
(89 \cdot 2 \%)\end{array}$} & \multirow{9}{*}{$\begin{array}{l}4 \cdot 95 \\
(117 \cdot 0 \%) \\
5 \cdot 10 \\
(105 \cdot 3 \%) \\
2 \cdot 76 \\
(67 \cdot 4 \%) \\
2 \cdot 95 \\
(65 \cdot 7 \%) \\
2 \cdot 89 \\
(87 \cdot 0 \%) \\
3 \cdot 38 \\
(101 \cdot 2 \%) \\
5 \cdot 37 \\
(107 \cdot 2 \%) \\
4 \cdot 67 \\
(104 \cdot 4 \%) \\
3 \cdot 32 \\
(97 \cdot 3 \%)\end{array}$} & $88 \cdot 4$ & \multirow{9}{*}{$\begin{array}{l}4 \cdot 50 \\
(102 \cdot 3 \%) \\
4 \cdot 21 \\
(96 \cdot 8 \%) \\
1 \cdot 56 \\
(33 \cdot 5 \%) \\
1.51 \\
(36 \cdot 8 \%) \\
1.97 \\
(57 \cdot 1 \%) \\
1.90 \\
(53 \cdot 1 \%) \\
5.70 \\
(115 \cdot 2 \%) \\
5 \cdot 50 \\
(116 \cdot 6 \%) \\
3.60 \\
(97 \cdot 3 \%)\end{array}$} & \multirow{9}{*}{$\begin{array}{l}1 \cdot 76 \\
(114.0 \%) \\
2 \cdot 25 \\
(139 \cdot 0 \%) \\
2 \cdot 19 \\
(160 \cdot 4 \%) \\
3 \cdot 12 \\
(165 \cdot 1 \%) \\
1.65 \\
(125 \cdot 0 \%) \\
1.40 \\
(111 \cdot 1 \%) \\
1.75 \\
104 \cdot 2 \%) \\
1.67 \\
(112 \cdot 0 \%)\end{array}$} & \multirow{9}{*}{$\begin{array}{l}7 \cdot 36 \\
(107 \cdot 9 \%) \\
9 \cdot 22 \\
(119 \cdot 8 \%) \\
6 \cdot 90 \\
(106 \cdot 2 \%) \\
8 \cdot 88 \\
(113 \cdot 6 \%) \\
5 \cdot 77 \\
(102 \cdot 5 \%) \\
6 \cdot 45 \\
(116 \cdot 4 \%) \\
7 \cdot 48 \\
(94 \cdot 0 \%) \\
6 \cdot 84 \\
(96.6 \%)\end{array}$} & \multirow{9}{*}{$\begin{array}{l}9.79 \\
(89.3 \%) \\
11.13 \\
(93.6 \%) \\
10.87 \\
(99.5 \%) \\
11.24 \\
(100.7 \%) \\
7.46 \\
(95.7 \%) \\
7.86 \\
(98.8 \%) \\
12.54 \\
(100.5 \%) \\
11.20 \\
(97.3 \%) \\
-\end{array}$} \\
\hline $2^{*}$ & $\mathbf{M}$ & $29 / 181$ & & & $74 \cdot 9$ & & & & \\
\hline 3 & $\mathbf{M}$ & $27 / 171$ & & & $59 \cdot 4$ & & & & \\
\hline 4 & $\mathbf{M}$ & $40 / 181$ & & & $50 \cdot 8$ & & & & \\
\hline 5 & $\mathbf{F}$ & $37 / 168$ & & & $70 \cdot 1$ & & & & \\
\hline $6^{*}$ & $\mathbf{F}$ & $31 / 167$ & & & $66 \cdot 9$ & & & & \\
\hline 7 & $\mathbf{M}$ & $22 / 183$ & & & 93.7 & & & & \\
\hline 8 & $\mathbf{M}$ & $25 / 176$ & & & $90 \cdot 3$ & & & & \\
\hline $9^{*}$ & $\mathbf{F}$ & $27 / 167$ & & & $87 \cdot 8$ & & & & \\
\hline
\end{tabular}

* Positive bronchial provocation testing with green coffee allergen.

Table 3 MEF50\% and MEF25\% before and after bronchodilator in coffee workers

\begin{tabular}{|c|c|c|c|c|c|c|c|c|}
\hline \multirow[t]{3}{*}{ Subject } & \multicolumn{4}{|l|}{ MEF50\% } & \multicolumn{4}{|l|}{$M E F 25 \%$} \\
\hline & \multirow{2}{*}{$\begin{array}{l}\text { Measured } \\
(l / s)\end{array}$} & \multirow[t]{2}{*}{$\%$ of normal } & \multicolumn{2}{|c|}{ After Alupent* } & \multirow{2}{*}{$\begin{array}{l}\text { Measured } \\
\text { (Vs) }\end{array}$} & \multirow[t]{2}{*}{ \% of normal } & \multicolumn{2}{|c|}{ After Alupent* } \\
\hline & & & $(l / s)$ & (\%) & & & $(l / s)$ & (\%) \\
\hline $\begin{array}{l}1 \\
2 \\
3 \\
4 \\
5 \\
6 \\
7 \\
8\end{array}$ & $\begin{array}{l}9.2 \\
5.2 \\
2.0 \\
2.6 \\
2.9 \\
2.8 \\
5.1 \\
5.3\end{array}$ & $\begin{array}{r}153.3 \\
83.9 \\
30.8 \\
44.4 \\
61.7 \\
59.5 \\
78.5 \\
81.5\end{array}$ & $\begin{array}{l}9.6 \\
6.8 \\
2.7 \\
2.6 \\
3.5 \\
3.1 \\
5.3 \\
5.6\end{array}$ & $\begin{array}{c}104 \cdot 3 \\
130 \cdot 8 \\
135.0 \\
0 \\
120.7 \\
98.3 \\
96.2 \\
94.6\end{array}$ & $\begin{array}{l}3.4 \\
2.5 \\
0.9 \\
0.9 \\
1.1 \\
1.5 \\
2.7 \\
2.7\end{array}$ & $\begin{array}{r}106.3 \\
75.8 \\
27.3 \\
31.6 \\
44.0 \\
55.6 \\
72.9 \\
77.1\end{array}$ & $\begin{array}{l}4.1 \\
3.6 \\
1.3 \\
0.9 \\
1.4 \\
1.9 \\
2.9 \\
2.9\end{array}$ & $\begin{array}{r}120.6 \\
144.0 \\
144 \cdot 4 \\
0 \\
127 \cdot 3 \\
78.9 \\
93 \cdot 1 \\
93.1\end{array}$ \\
\hline
\end{tabular}

${ }^{*}$ Bromhexine/orciprenaline.

In the case of a considerable fall in ventilatory capacity the subjects were given a bronchodilator.

\section{EXPERIMENTAL EXPOSURE IN HEALTHY \\ SUBJECTS}

Subjects

A group of six healthy volunteers aged 23 to 48 with no allergic symptoms and who had never been occupationally exposed to green or roasted coffee were experimentally exposed to green coffee dust emitted in a coffee roasting plant for 45 minutes during the cleaning of the exhaust system.

\section{Lung function measurement}

Ventilatory capacity was measured by recording MEFV curves before exposure and at the end of a 45 minute exposure. The maximum expiratory flow rate at $50 \%$ and the last $25 \%$ of the VC were determined from these curves (MEF50\%, MEF25\%).

\section{Environmental measurements}

Airborne dust was sampled with personal samplers worn by the subjects during their experimental exposure. Total dust and respirable dust concentrations were determined.

\section{Results}

\section{STUDY IN COFFEE WORKERS}

Respiratory symptoms

Table 1 shows the prevalence of chronic respiratory symptoms, smoking habits, results of intradermal skin tests, and IgE serum levels in the coffee workers. Of the nine coffee workers who complained of respiratory difficulties, six had symptoms of occupational asthma, five had chronic bronchitis, and eight chronic rhinitis. Only one had chronic sinusitis. All complained of acute symptoms such as rhinorrhea, sneezing, and watering and itching of the eyes after exposure to coffee dust. These symptoms were noted in both smokers and non-smokers.

\section{Lung function measurement}

The lung function data are presented in tables 2 and 3. All subjects had normal values for FEV, but two 


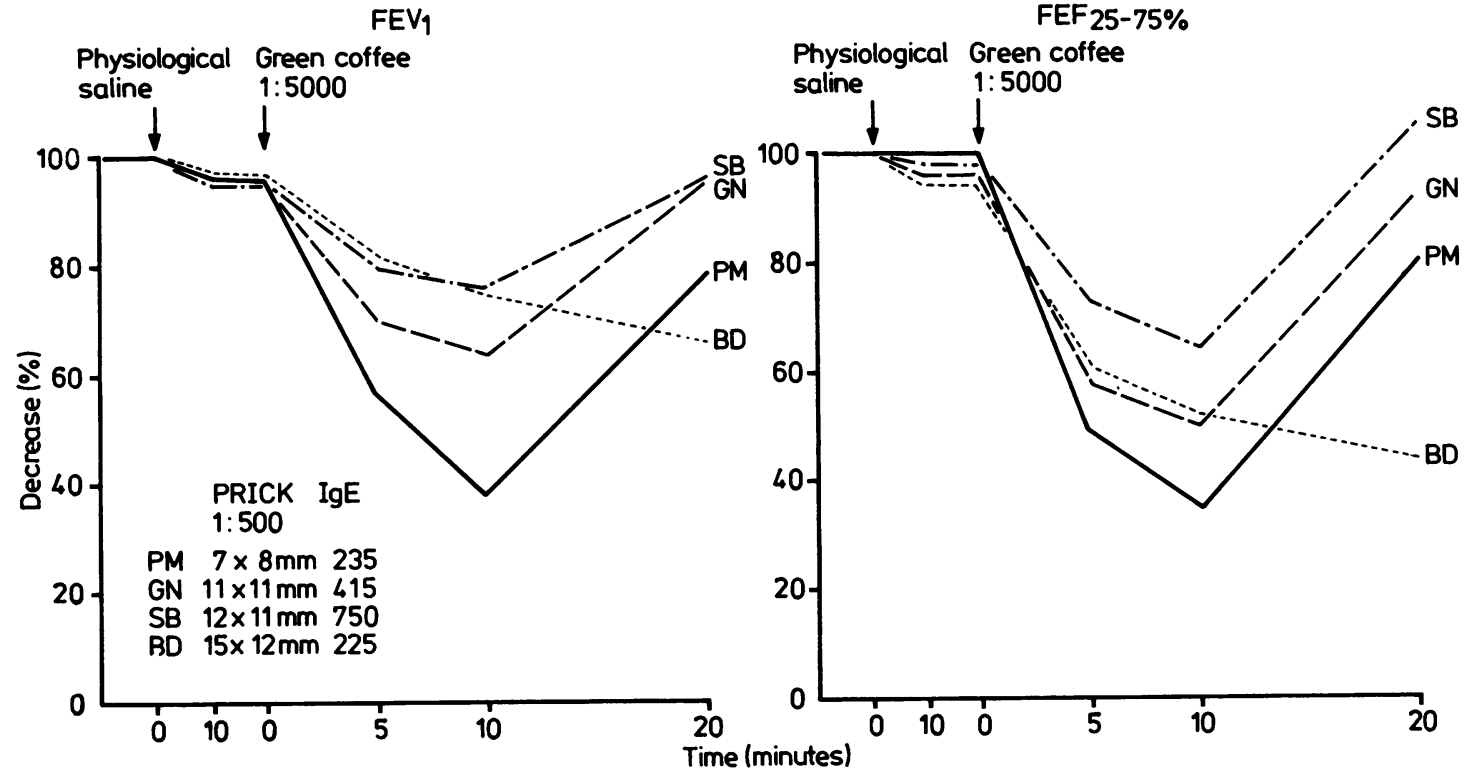

Relative acute reductions of ventilatory capacity in four workers after bronchoprovocation with physiological saline and green coffee allergen. Prick tests with green coffee allergen were positive. IgE serum levels (PRIST) were increased. Subjects: PM (No 6); GN (No 2); $S B$ (No 1); BD (No 9).

had an FEV 1 less than $80 \%$ of expected $(67.4 \%$ and $65.7 \%$ ). In four subjects the $\mathrm{FEF}_{25-75 \%}$, MEF50\%, and MEF $25 \%$ were less than $70 \%$ of the normal values (tables 2 and 3); the RV was considerably increased in three workers $(139.0 \%, 160.4 \%$, $165 \cdot 1 \%)$. The $\mathrm{DL}_{\mathrm{CO}}$ was within normal values in all subjects, indicating that exposure to coffee dust did not effect intrapulmonary gas exchange.

The inhalation of bromhexine/orciprenaline (Alupent) considerably increased the measured MEF50\% and MEF25\% values in all but one worker (table 3 ) indicating the obstructive changes in most of the subjects were reversible.

Immunological studies

Positive intradermal skin tests to green coffee allergen were found in six workers; one only had a positive skin reaction to roasted coffee (table 1).

In eight of the nine coffee workers the IgE level in the serum was considerably higher than normal (range: 148-1000 IU/ml) (table 1).

\section{Bronchial provocation testing}

Four of the nine workers showed a considerable decrease of ventilatory capacity at five and 10 minutes after inhaling green coffee (fig). These four complained of upper and lower respiratory symptoms at work and they had a positive skin prick test and serum IgE levels ranging from 235 to $750 \mathrm{IU} /$ $\mathrm{ml}$. Acute reductions in $\mathrm{FEV}_{1}$ varied from $18 \%$ to $43 \%$ at five minutes and from $24 \%$ to $62 \%$ at 10 minutes after inhalation. Acute reductions in

Table 4 Acute changes in ventilatory capacity in six healthy subjects experimentally exposed to coffee dust in the working environment

\begin{tabular}{|c|c|c|c|c|c|c|c|c|c|c|}
\hline \multirow{2}{*}{$\begin{array}{l}\text { Subject } \\
\text { No }\end{array}$} & \multirow[t]{2}{*}{$\operatorname{Sex}$} & \multirow{2}{*}{$\begin{array}{l}\text { Age } \\
\text { (y) }\end{array}$} & \multicolumn{2}{|l|}{$F V C$} & \multicolumn{2}{|l|}{$F E V_{\text {, }}$} & \multicolumn{2}{|c|}{ MEF50\% } & \multicolumn{2}{|c|}{$M E F 25 \%$} \\
\hline & & & $\begin{array}{l}\text { Before } \\
\text { (l) }\end{array}$ & $\begin{array}{l}\text { Difference } \\
\text { before after } \\
\text { (\%) }\end{array}$ & $\begin{array}{l}\text { Before } \\
\text { (l) }\end{array}$ & $\begin{array}{l}\text { Difference } \\
\text { before after } \\
\text { (\%) }\end{array}$ & $\begin{array}{l}\text { Before } \\
(l / s)\end{array}$ & $\begin{array}{l}\text { Difference } \\
\text { before after } \\
\text { (\%) }\end{array}$ & $\begin{array}{l}\text { Before } \\
(l / s)\end{array}$ & $\begin{array}{l}\text { Difference } \\
\text { before after } \\
\text { (\%) }\end{array}$ \\
\hline $\begin{array}{l}1 \\
2 \\
3 \\
4 \\
5 \\
6\end{array}$ & $\begin{array}{l}\mathbf{F} \\
\mathbf{F} \\
\mathbf{F} \\
\mathbf{F} \\
\mathbf{M} \\
\mathbf{M}\end{array}$ & $\begin{array}{l}30 \\
23 \\
49 \\
45 \\
31 \\
29\end{array}$ & $\begin{array}{l}4.20 \\
3.73 \\
3.50 \\
3.27 \\
4.47 \\
6.68\end{array}$ & $\begin{array}{c}-1.4 \\
-2.1 \\
0 \\
-0.9 \\
-1.1 \\
-1.6\end{array}$ & $\begin{array}{l}3.45 \\
3.62 \\
2.75 \\
2.47 \\
3.85 \\
4.83\end{array}$ & $\begin{array}{c}-2 \cdot 0 \\
-3 \cdot 6 \\
0 \\
-3 \cdot 2 \\
0 \\
-1 \cdot 2\end{array}$ & $\begin{array}{l}5 \cdot 8 \\
5 \cdot 4 \\
4 \cdot 0 \\
2 \cdot 6 \\
6 \cdot 9 \\
5 \cdot 4\end{array}$ & $\begin{array}{l}-13.8 \\
-\quad 3.7 \\
-10.0 \\
-7.7 \\
-10.1 \\
-7.4\end{array}$ & $\begin{array}{l}2 \cdot 5 \\
3 \cdot 2 \\
1 \cdot 8 \\
1 \cdot 7 \\
2 \cdot 5 \\
2 \cdot 3\end{array}$ & $\begin{array}{l}-23 \cdot 8 \\
-3 \cdot 1 \\
-22 \cdot 2 \\
-41 \cdot 1 \\
-20 \cdot 0 \\
-21 \cdot 7\end{array}$ \\
\hline
\end{tabular}


$\mathrm{MEF}_{25-75 \%}$ were larger, varying from $28 \%$ to $51 \%$ at five minutes and from $50 \%$ to $66 \%$ at 10 minutes after coffee challenge. Ten minutes after the inhaling the green coffee allergen, two subjects were given bromhexine/orciprenaline (Alupent) and one subject was given parenteral aminophylline. Subject PM who had the largest acute reductions was followed up for 24 hours. No late reaction was noted, and at 24 hours lung function was within normal limits.

\section{EXPERIMENTAL EXPOSURE IN HEALTHY SUBJECTS}

\section{Lung function measurement}

In the six healthy sujects who were experimentally exposed to green coffee dust (table 4) the largest acute reductions, as a percentage of the control values, were recorded for MEF $25 \%$ (range: $3.1 \%$ to $41 \cdot 1 \%$ ). Five subjects reacted with acute reductions in MEF50\% (range: $3.7 \%$ to $13.8 \%$ ) and four subjects with acute reductions in $\mathrm{FEV}_{1}$ (range: $1.2 \%$ to $3.6 \%$ ). These data indicate that acute exposure to green coffee dust may cause acute obstructive changes in the smaller airways. Four of the six subjects complained of cough, chest tightness, and shortness of breath during the 45 minute exposure to green coffee dust. Relative acute reductions in FVC were considerably smaller (range: $0-2 \cdot 1 \%$ ).

\section{Environmental measurements}

Dust concentrations of green coffee during the experimental exposures were: mean total dust 5.6 $\mathrm{mg} / \mathrm{m}^{3}$ and respirable dust, $0.7 \mathrm{mg} / \mathrm{m}^{3}$.

\section{Discussion}

The present study indicates that exposure to dust during coffee processing is likely to cause the development of chronic respiratory symptoms and changes in lung function in coffee workers. These data are in agreement with our previous epidemiological investigation of coffee workers in which we showed a significantly higher prevalence of chronic respiratory symptoms in exposed workers compared with a non-exposed referent group. ${ }^{67}$

All nine workers included in the present study complained of occupational allergic manifestations, such as rhinitis, expiratory dyspnoea, conjuctivitis, or headache shortly after starting work. They all noted an improvement in their symptoms when not working, particularly at weekends and during vacations. Two workers reported the onset of wheezing soon after starting work in the coffee industry.

In our study the provocative inhalation of a green coffee allergen caused bronchoconstriction in four of the nine workers tested. They showed an immedi- ate reaction, none showed a late reaction. Karr et al and Karr found a significant immediate asthmatic reaction in two skin test and RAST positive subjects after provocative inhalation challenge with green coffee dust. ${ }^{518}$ The authors failed, however, to produce an airway response in a skin and RAST negative asthmatic subjects.

The effect of coffee allergen in our workers was particularly noticeable on flow rates at low lung volumes. The $\mathrm{FEF}_{25-75 \%}$ was a more sensitive test than the $F E V_{1}$ in detecting broncho-obstructive changes after provocative inhalation challenge with the green coffee allergen. Such a pattern of airways constriction suggests that the small airways are primarily affected in the response. Similar results were observed in inhalation studies with aqueous extracts of cotton dust ${ }^{19}$ or hemp dust ${ }^{20}$ indicating that changes in the flow rates on maximum or partial expiratory flow volume curves are more sensitive than the $F E V_{1}$ in detecting the acute effects of such agents. No changes in diffusing capacities were found in our workers, although we had studied workers exposed both for long periods (14 to 17 years) and short periods ( 3 and 4 years).

All the workers with positive bronchial provocation test had positive skin reaction to green coffee. These results indicate that skin reactions to green coffee allergen have a great specificity for detecting workers sensitive to green coffee. In all the workers with positive bronchoprovocation tests, the IgE levels were above the normal values.

The experimental study with six volunteers suggested that even a short exposure (45 minutes) to green coffee dust may cause an acute reduction in flow rate. Four of the six subjects complained of chest tightness and difficulty in breathing during exposure.

An aqueous extract of green coffee produced contraction in smooth muscle isolated from the trachea of guinea pigs whereas an extract of roasted coffee did not. ${ }^{21}$ Such data suggest that extracts of coffee dust have a biological activity that changes from a contractile to a relaxant effect as a consequence of processing. Osterman et al reported that raw coffee bean dust seems to have moderately potent allergen..$^{22}$ The same authors emphasised the importance of atopic status, degree and duration of exposure and smoking habit as predisposing factors in the development of sensitivity to coffee bean dust.

Our study indicates that occupational challenge tests, skin tests, and the serum reagin titre are important in determining the sensitivity of airways to green coffee allergen. Such tests should be used in medical examinations as a means by which to identify workers sensitive to coffee dust. Atopic workers or those with non-specific bronchial hyperreactivity 
should be followed up and, if their lung function becomes impaired or they develop respiratory symptoms, they should be moved to another job.

\section{References}

' Bruun E. Allergy to coffee. An occupational disease. Acta Allergologica 1957;11:150-4.

${ }^{2}$ Lehrer SB, Karr RM, Salvaggio JE. Analysis of green coffee bean and castor bean allergens using RAST inhibition. Clin Allergy 1981;11:357-66.

${ }^{3}$ Turula M, Aho J, Taipale S, Forstrom L. Raw coffee allergy among coffee roastery workers. XV International Congress of Occupational Health, Vienna, 1966. Vol II. Vienna: TuschDruck Ges, 1966:845-8,

${ }^{4}$ Van Toorn DW. Coffee worker's allergy. A new example of extrinsic allergic alveolitis. Thorax 1970;25:399-405.

${ }^{5}$ Karr RM, Lehrer SB, Butcher BT, Salvaggio JE. Coffee worker's asthma: a clinical appraisal using the radioallergosorbent test. Allergy Clin Immunol 1978;62:143-8.

- Žuškin E, Valić F, Skurić Z. Respiratory function in coffee workers. Br J Ind Med 1979;36:117-22.

7 Žuškin E, Valić F, Kanceljak B. Immunological and respiratory changes in coffee workers. Thorax 1981;36:9-13.

${ }^{8}$ Somazzi S, Wütrich B. Asthme profesionnel à la poussiére de café vert. Medicine et Hygiene 1975;33:677-83.

' Žuškin E, Duncan PG, Douglas JS. Pharmacological characterization of extracts of coffee dusts. $\mathrm{Br} J$ Ind Med 1983; 40:193-8.

${ }^{10}$ Medical Research Council Committee on the Aetiology of Chronic Bronchitis. Standardized questionnaire on respiratory symptoms. Br Med J 1960;ii: 1665.
"Commissiòn des Communautés Européennes, CECA. Aidememoire pour la pratique de l'examen de la fonction ventilatoire per la spirographic. Luxembourg: CECA 1971. (Collection d'hygiene et de medicine du travail, No 11.)

${ }^{12}$ Morris J, Koski A, Johnson LC. Spirometric standards for healthy nonsmoking adults. Am Rev Respir Dis 1971;103:57-67.

${ }^{13}$ Cherniack RM, Raber MB. Normal standards for ventilatory function using an automated wedge spirometer. Am Rev Respir Dis 1972;106:38-46.

14 Cotes JE. Lung function. Oxford: Blackwell Scientific Publications, 1965.

is Mimica M. Kožni testovi. Medicinska enciklopedija. Zagreb: Jugoslovenski leksikografski zavod, 1969:107-8.

${ }^{16}$ Wide L, Porath J. Radioimmunoassay of proteins with the use of Sephadexcoupled antibodies. Biochimica et Biophysica Acta 1966; 130:257-60.

${ }^{17}$ Pepys J, Hutchcroft B. Bronchial provocation test in etiologic diagnosis and analysis of asthma. Am Rev Respir Dis 1975;112:829-59.

${ }^{18} \mathrm{Karr}$ RM. Bronchoprovocation studies in coffee worker's asthma. J Allergy Clin Immunol 1979;64:650-4.

19 Schachter EN, Browen S, Žuškin E, et al. The effect of mediator modifying drugs in cotton bract-induced bronchospasm. Chest 1981;79s: 73-7.

${ }^{20}$ Žuškin E, Bouhuys A. Protective effect of disodium cromoglycate against airway constriction caused by hemp dust extract. $J$ Allergy Clin Immunol 1976;57:473-9.

21 Žuškin E, Duncan PG, Douglas JS. The pharmacological characterization of aqueous extracts of vegetable dusts. Lung 1983;161:301-6.

${ }^{22}$ Osterman K, Zetterstrom O, Johansson SGO. Coffee worker's allergy. Allergy 1982;37:313-22. 